\title{
Implementation of Problem-based Learning - Flipped Classroom Model in Chemistry and Its Effect on Scientific Literacy
}

\author{
Maria Paristiowati*, Ucu Cahyana, Bening Irsa Setara Bulan \\ Department of Chemistry Education, State University of Jakarta, Indonesia
}

Received July 9, 2019; Revised September 9, 2019; Accepted September 16, 2019

Copyright $@ 2019$ by authors, all rights reserved. Authors agree that this article remains permanently open access under the terms of the Creative Commons Attribution License 4.0 International License

\begin{abstract}
This study aims to determine the effect of the problem-based learning - flipped classroom model and critical-thinking skills toward students' scientific literacy on the topic of reaction rates. The implementation of the problem-based learning - flipped classroom model is considered appropriate for developing students' criticalthinking skills and scientific literacy. The learning time in the classroom becomes more effective and through a problem-solving process, the students can develop critical-thinking skills, and it is hoped that students' scientific literacy can also develop. This research used the true experiment method with two-way ANOVA research design (2x2 treatment by level design). Seventy two students at one of the senior high schools in Jakarta become samples. Data collection techniques in this study are through tests of critical-thinking skills and scientific literacy tests. The results showed that the model of problem-based learning-flipped classroom influenced student's scientific literacy on chemical reaction rate. Each model gives different effect towards the students' scientific literacy, if it is applied to students who have different critical-thinking skills. The model of problem-based learning-flipped classroom is more effectively applied to the students who have high critical-thinking skills.
\end{abstract}

Keywords Flipped Classroom, Problem-based Learning, Scientific Literacy

\section{Introduction}

Along with the development of science and technology that grows fast in the 21st-century, it encourages education from other countries to develop a learning model that supports $21^{\mathrm{st}}$-century skills, such as critical thinking and problem solving, communication and collaboration, creativity and innovation, developing literacy of information technology and communication, ability to study contextual and then ability to literate information and media. Recently, learning model that supports 21st-century skills has already applied in learning activities in Indonesia. It can be seen from the use of some media based ICT, such as power point, flash player, learning video, website and others to support learning process.

The approach orientating the problem can impact that promises to chemistry learning in developing ability of high thinking, such as the critical-thinking skills that are followed by the development of students' scientific literacy (Marks \& Eilks, 2009). The development of critical-thinking skills is also expected to improve students' scientific literacy. PISA 2015 expressed that scientific literacy is the ability to be involved inside the problems that concern science and scientific ideas, as a reflective society. Through scientific literacy, students can deeply understand about science and technology so that it can contribute to the environment. Scientific literacy also can be the bridge for the students to give the solution for the problems that happened in the environment, especially the problems that were concerned with science and technology so it can make them adapted well in the environment and then compete in the real world.

The flipped classroom model can be one of the learning models that are effective for chemistry learning in the class. It is learning activity that traditionally can be conducted in the class, now it can be conducted outside the class. Information delivery can be conducted by using media online, such as learning video (Lage, Platt, \& Treglia, 2000). Next during the class, it will be conducted feedback activity, such as discussion, problem solving or tests (Osman, Jamaludin, \& Mokhtar, 2014). The flipped classroom learning model can be supported by another learning model like problem-based learning that gives 
positive impact, such as improving students' result study, motivation, activeness, and building the interaction between teachers and students, compared with traditional learning model (Tawfik \& Lilly, 2015). Problem-based learning model is one of the learning models that are suggested in the implementation 2013 curriculum in Indonesia. It is one of the ways to build and teach by using the problem as stimulus and focus on student's activities. In problem-based learning model, students usually work to solve the problem in a group, meanwhile the role of teacher is presenting the problems, asking, and facilitating the investigation and students' dialogue.

Some researches show that the implementation of problem-based learning model impacts positively towards chemistry learning, like students' result study on electrochemical topic (Günter \& Alpat, 2017). Problem-based learning model as active learning approach has a positive impact in improving result study, resolving alternative conceptual, and improving student's positive perception towards learning activities on an acid base topic (Tarhan \& Acar-Sesen, 2013). It impacts positively towards the skill of the student's scientific process on the topic of solution and physical properties, improving student's access to use their knowledge, cooperate in groups, independent learning and the ability of solving a problem (Tosun \& Taskesenligil, 2013).

The implementation of the model expected that science learning at school, especially chemistry, not only focuses on the product and delivery of content scientific learning, but also can be more focused on the process of science outcomes, for example, through discussion process and problem solving about science and technology in the environment. Therefore, students can improve skills of critical thinking and deepen understanding about science and technology so that they can develop scientific literacy.

\section{Literature Review}

Flipped classroom is a learning model that has been applied by many teachers in the world. The concept of the flipped classroom was submitted by Bergmann and Sams in 2012. They recorded classroom learning and provided online videos so students could watch and review subject matter easily. The strategy provides significant results that inspire them to use further online learning videos for learning before meeting in class. Some studies suggest that flipped classroom learning has a positive effect on student learning outcomes and has a positive impact on students' attitudes toward chemistry, where students can be directly involved and active in learning activities. (Olakanmi, 2017), (McDonald \& Smith, 2013), (Eichler \& Peeples, 2016).

According to Abeysekera and Dawson 2014; Bishop and Verleger 2013; Kim et al., 2014, there are several characteristics of classroom flipped learning models, including the flipped classroom learning model facilitating students at lower cognitive levels outside the class, namely remembering (C1) and understanding (C2). Furthermore, developing a higher cognitive level when inside the class (inside class), which is applying (C3), analyzing (C4), and evaluating (C5) (Inga Hahn et. Al, 2013). Kong's research (2014) suggests that students have a statistically significant development in Information Literacy (IL) competencies and critical thinking skills through the creation of digital classrooms, using the Flipped Classroom strategy.

Flipped classroom learning models can be combined with or supported by other learning models such as problem based learning which turns out to provide better results, related learning outcomes, deeper student understanding, student motivation, student activity, and build teacher and student interactions, compared to learning models traditional (Traditional Classroom). (Tawfik \& Lilly, 2015). Some studies on the effect of problem based learning report positive results on the learning outcomes (Günter \& Alpat, 2017), addressing alternative concepts, and improving students' positive perceptions of learning activities in Acid-Basa (Tarhan \& Acar-Sesen, 2013) material, positively impacting science process skills (scientific processing skills) of students on the topic of Solution and its Physical Characteristics in the General Chemistry II course, as well as increasing the level of students in accessing and using their knowledge, working in groups and working together, independent learning, and problem solving abilities (Tosun \& Taskesenligil, 2013).

The implementation of the inquiry flipped classroom learning model increases students' motivation and students have a better understanding than students who are not using this learning model. (Paristiowati, Fitriani, \& Aldi, 2017). The combination of classroom contextual-flipped learning models also has an impact on improving student scientific literacy, which means students can identify components in complex situations, apply both concepts and knowledge about science and can compare, choose, and evaluate the scientific evidence that is appropriate to respond to life situations (Paristiowati, 2019). Science literacy is seen by most education experts as something that is important for the welfare of society, namely as the ability of individuals to play a role in 21st century science and a world dominated by technology. According to (Deboer, 2000) scientific literacy allows people to live effectively in a rapidly changing nature (Celik, 2014). So, rather than focusing solely on memorizing knowledge, scientific literacy reflects a person's ability to apply scientific knowledge that exists in several contexts and situations in everyday life (Hahn et al., 2013)

\section{Methodology/Materials}

This research was conducted at one of the senior high 
school in Jakarta. It used true experiment method with ANOVA design treatment by level $2 \times 2$. This research involved two groups; the experiment group was applied by problem-based learning-flipped classroom model, and the control group was applied by problem-based learning-traditional classroom model. The data of scientific literacy between two groups was analyzed based on the differences of students' critical-thinking skills. ANOVA design treatment by level $2 \times 2$ in this research is as follow:

Table1. ANOVA Design Treatment by Level 2x2

\begin{tabular}{|c|c|c|}
\hline \multirow{2}{*}{$\begin{array}{c}\text { Critical Thinking } \\
\text { Skills (B) }\end{array}$} & \multicolumn{2}{|c|}{ Learning Model } \\
\cline { 2 - 3 } & $\begin{array}{c}\text { PBL-Flipped } \\
\text { Classroom }\left(\mathrm{A}_{1}\right)\end{array}$ & $\begin{array}{c}\text { PBL-Traditional } \\
\text { Classroom }\left(\mathrm{A}_{2}\right)\end{array}$ \\
\hline $\begin{array}{c}\text { High Critical } \\
\text { Thinking }\left(\mathrm{B}_{1}\right)\end{array}$ & $\mathrm{A}_{1} \mathrm{~B}_{1}$ & $\mathrm{~A}_{2} \mathrm{~B}_{1}$ \\
\hline $\begin{array}{c}\text { Low Critical } \\
\text { Thinking }\left(\mathrm{B}_{2}\right)\end{array}$ & $\mathrm{A}_{1} \mathrm{~B}_{2}$ & $\mathrm{~A}_{2} \mathrm{~B}_{2}$ \\
\hline
\end{tabular}

Participants in this research are 72 students who were taken from grade 10th science program in senior high school in Jakarta. Sampling method in the research was conducted with the technical of simple random sampling. Students are divided into two groups that are applied for different learning model, problem-based learning-traditional classroom and problem-based learning-flipped classroom. The students in each group are also given the test to determine critical-thinking skills;
$27 \%$ of the highest score for the group that had the high critical-thinking skills and $27 \%$ of the lowest score as the group that had low critical-thinking skills.

The data in this research was collected by the test of scientific literacy and the test of critical-thinking skills. Before being analyzed, the data was tested for normality by Liliefor's test and homogeneity by Fisher test and Bartlett's test. There were four hypotheses that were tested in this research. The first hypothesis test (main effect) and second (interaction effect) were using technical analysis variance (ANOVA) two ways, meanwhile the third and the fourth (simple effect) were using Tukey test.

\section{Results and Findings}

The results of the hypothesis test are shown in table 2 . The score describes that $F_{c}>F_{t}$ at a significant level $\alpha=0.05$; it means that students' scientific literacy with model problem-based learning-flipped classroom was higher than those who were given model problem-based learning-traditional classroom. The second result, the score $\mathrm{F}_{\mathrm{c}}>\mathrm{F}_{\mathrm{t}}$ at a significant level $\alpha=0.05$; it can be concluded that there was an interaction between learning model and the critical-thinking skills (dependent variables) towards students' scientific literacy (independent variable). It can be seen in figure 1 .

Table 2. The result of hypothesis test using ANOVA two ways

\begin{tabular}{|c|c|c|c|c|c|}
\hline Variance Source & ds & SS & MS & $F_{\text {calculation }}$ & $F_{\text {table }}(\alpha=0.05)$ \\
\hline Between $\mathrm{A}_{1}$ and $\mathrm{A}_{2}$ & 1 & 313.60 & 313.60 & 10.94 & 4.10 \\
\hline Interaction A X B & 1 & 1690.00 & 1690.00 & 58.93 & 4.10 \\
\hline In group & 36 & 1032.40 & 28.68 & - & \\
\hline Total (T) & 40 & 245294.00 & - & - & \\
\hline
\end{tabular}

df: degree of freedom

SS: sum square

MS: mean square

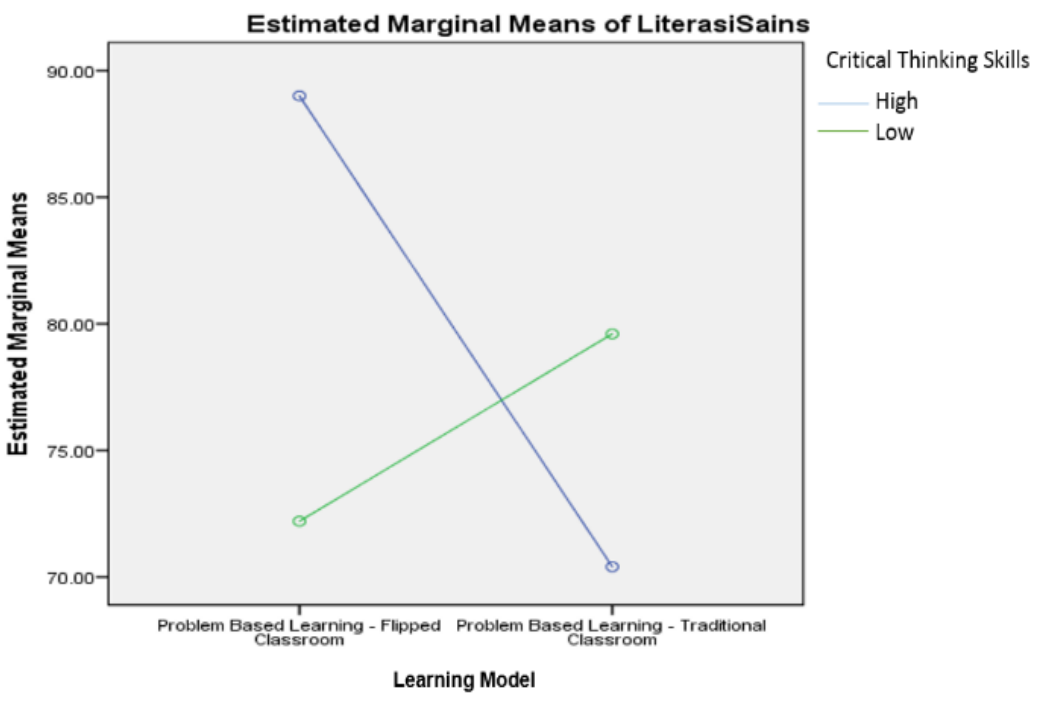

Figure 1. Interaction effect between learning model and critical thinking skills 
Figure 1 shows that each learning model gives different effect towards student's scientific literacy, if it is applied to students groups that have different critical-thinking skills. The results of Tukey test are shown in table 3 . In the students group that has high critical-thinking skills, the score describes that students' scientific literacy that is given problem-based learning flipped classroom model was higher than those who are given problem-based learning-traditional classroom model. Otherwise, student's scientific literacy that was given the model of problem-based learning flipped classroom model was lower than the model of the problem-based learning-traditional classroom model in the students group that had low critical-thinking skills.

Table 3. The result of hypothesis test using Tukey test

\begin{tabular}{|c|c|c|c|}
\hline Group & Qcalculation & Qtable & Conclusion \\
\hline $\mathrm{A}_{1} \mathrm{~B}_{1}-\mathrm{A}_{2} \mathrm{~B}_{1}$ & 10.98 & 4.33 & $\mathrm{H}_{0}$ rejected \\
\hline $\mathrm{A}_{1} \mathrm{~B}_{2}-\mathrm{A}_{2} \mathrm{~B}_{2}$ & 4.37 & 4.33 & $\mathrm{H}_{0}$ rejected \\
\hline
\end{tabular}

The students' scientific literacy that is given the model of problem-based learning-flipped classroom is higher compared with that are given problem-based learning-traditional classroom model. It is caused, learning in the class can be more effective because the learning material has been given by the teachers outside the class through video of learning. Students can prepare themselves for the learning in class by watching video, and they can construct the prior knowledge before learning activities in class. Therefore, the practice or discussion in the class can be done more to involve the students in deeper learning and assists them to clarify misconception (Hwang, Lai, \& Wang, 2015). It is the same opinion that flipped classroom reconstruct the environment in the class and the activities at home (Bergmann \& Sams, 2012). In the flipped classroom, teachers can reduce the duration to explain learning material and increase the time for active learning, such as discussion and problem solving (Bishop \& Verleger, 2013).

It is different from learning using problem-based learning-traditional classroom model. In this model, the teachers deliver the learning material in the class through direct instruction using media power point, then continued with giving the problem and student discuss to solve it. The model of problem-based learning-traditional classroom less involved the students directly to be active in deeper learning activities. Students who are given this model less have deep understanding about science and technology and can be the impact to the low scientific literacy. Some researches about the implementation of a model flipped classroom also show positive impact compared with model traditional learning, such as result study and student's behavior towards chemistry, making active learning, preparing students before learning in the class, and then assisting them in solving homework, preparing the exam, strengthening and clarifying the concept (Eichler \&
Peeples, 2016; Olakanmi, 2017).

The result of the hypothesis test shows that there is the effect of interaction between learning model and critical-thinking skills towards the students' scientific literacy on a chemical reaction rate topic. The interaction proves that each learning model gives different effect towards students' scientific literacy if applied to students groups that have different critical-thinking skills. Scientific literacy has become one of the main purposes that should be achieved by the students. OECD states that one of the competencies that have special significance and relevance with scientific literacy is critical thinking. Students who have the critical-thinking skills are expected to be involved in criticizing the problems that happened around the environment, especially the problems about science and technology, and to give a solution of the problems. Critical thinking is the ability to solve the problems, collect and analyze evidence, and use analysis to decide. (Nargundkar, Samaddar, \& Mukhopadhyay, 2014). The model of flipped classroom gets the cognitive level that is lower outside the class; it is to remind (C1) and understand (C2). Next, it is focused on the high level of cognitive during in the class, by applying (C3), analyzing (C4) and evaluating (C5) (Paristiowati et al., 2017). Another research shows that the approach of a problem oriented can impact promise to chemical learning in developing the ability of high-order thinking and students' scientific literacy (Malik, Paraherakis, Joseph, \& Ladd, 1996; Marks \& Eilks, 2009).

The problem-based flipped classroom learning models are good if applied to students who have high critical-thinking skills. Through the implementation of the flipped classroom model, students can obtain sufficient knowledge before starting learning. They have more time to do high-level learning in the classroom, and then it can increase their motivation and result study (Hwang et al., 2015). In the flipped classroom model, students who have high critical-thinking skills can apply their knowledge from videos learned at home and actively engage in deeper learning activities while in class, such as discussion and problem solving. Students can be trained to use high critical-thinking skills to solve problems in around the environment that is about science and technology so it is impacted to high scientific literacy.

\section{Conclusions}

The conclusion in this research shows that implementation of the right learning model, and consideration of the students' characteristics based on the level of critical-thinking skills, can give the positive effect to students' scientific literacy. The problem-based learning-flipped classroom model is more effectively applied to the student who has high critical thinking, while the problem-based learning-traditional classroom model is more effectively applied to the student who has low critical 
thinking.

\section{Acknowledgements}

This work is supported by Universitas Negeri Jakarta and Ministry of Research, Technology and Higher Education of the Republic of Indonesia through research fund 2017-2018.

\section{REFERENCES}

[1] Bergmann, J., \& Sams, A. (2012). Flip Your Classroom: Reach Every Student in Every Class Every Day (First Edit). United States of America: International Society for Technology in Education.

[2] Bishop, J., \& Verleger, M. (2013). Testing the flipped classroom with model-eliciting activities and video lectures in a mid-level undergraduate engineering course. Proceedings - Frontiers in Education Conference, FIE, 161163. https://doi.org/10.1109/FIE.2013.6684807

[3] Celik, S. (2014). Chemical Literacy Levels of Science and Mathematics Teacher Candidates, 39(1).

[4] Deboer, G. E. (2000). Scienti ${ }^{\circledR}$ c Literacy : Another Look at Its Historical and Contemporary Meanings and Its Relationship to Science Education Reform, 37(6), 582-601.

[5] Eichler, J. F., \& Peeples, J. (2016). Flipped classroom modules for large enrollment general chemistry courses: A low barrier approach to increase active learning and improve student grades. Chemistry Education Research and Practice, 17(1), 197-208. https://doi.org/10.1039/c5rp0015 9e

[6] Günter, T., \& Alpat, S. K. (2017). The effects of problem-based learning (PBL) on the academic achievement of students studying 'Electrochemistry.' Chem. Educ. Res. Pract., 18(1), 78-98. https://doi.org/10.1039/C6 RP00176A

[7] Hahn, I., Marie, I., Schöps, K., Rönnebeck, S., Martensen, M., Hansen, S., \& Dalehefte, I. M. (2013). Assessing scientific literacy over the lifespan - a description of the NEPS science framework and the test development Assessing scienti fi c literacy over the lifespan - A description of the NEPS science framework and the test development. Journal for Educational Research Online, 5(2), 110-138.

[8] Hwang, G.-J., Lai, C.-L., \& Wang, S.-Y. (2015). Seamless flipped learning: a mobile technology-enhanced flipped classroom with effective learning strategies. Journal of Computers in Education, 2(4), 449-473. https://doi.org/10. 1007/s40692-015-0043-0

[9] Lage, M. J., Platt, G. J., \& Treglia, M. (2000). Inverting the classroom: A gateway to creating an inclusive learning environment. The Journal of Economic Education, 31(1), $30-43$.

[10] Malik, R., Paraherakis, A., Joseph, S., \& Ladd, H. (1996).
The method of subliminal psychodynamic activation: do individual thresholds make a difference? Perceptual and Motor Skills, 83(3), 1235-1242. https://doi.org/01.2013/JC PSP.4246

[11] Marks, R., \& Eilks, I. (2009). Promoting Scientific Literacy Using a Sociocritical and Problem-Oriented Approach to Chemistry Teaching: Concept, Examples, Experiences, 4(3), 231-245.

[12] McDonald, K., \& Smith, C. M. (2013). The Flipped Classroom for Professional Development : 44(10). https://d oi.org/10.3928/00220124-20130925-19

[13] Nargundkar, S., Samaddar, S., \& Mukhopadhyay, S. (2014). A guided problem-based learning (PBL) approach: Impact on critical thinking. Decision Sciences Journal of Innovative Education, 12(2), 91-108. https://doi.org/10.11 11/dsji.12030

[14] Olakanmi, E. E. (2017). The Effects of a Flipped Classroom Model of Instruction on Students' Performance and Attitudes towards Chemistry. Journal of Science Education and Technology, 26(1), 127-137. https://doi.org/10.1007/s 10956-016-9657-x

[15] Osman, S. Z. M., Jamaludin, R., \& Mokhtar, N. E. (2014). Flipped Classroom and Traditional Classroom: Lecturer and Student Perceptions between Two Learning Cultures, a Case Study at Malaysian Polytechnic. International Education Research, 2(4), 16-25. https://doi.org/10.12735/ ier.v2i4p16

[16] Paristiowati, M. (2019). Analysis of students' scientific literacy in contextual-flipped classroom learning on acid-base topic Analysis of students' scientific literacy in c ontextual-flipped classroom learning on acid-base topic. Journal of Physics: Conference Series. https://doi.org/10.1 088/1742-6596/1156/1/012026

[17] Paristiowati, M., Fitriani, E., \& Aldi, N. H. (2017). The effect of inquiry-flipped classroom model toward students' achievement on chemical reaction rate. AIP Conference Proceedings, 1868(August). https://doi.org/10.1063/1.4995 105

[18] Tarhan, L., \& Acar-Sesen, B. (2013). Problem Based Learning in Acids and Bases: Learning Achievements and Students' Beliefs. Journal of Baltic Science Education, 12(5), 565-578. https://doi.org/1648-1652

[19] Tawfik, A. A., \& Lilly, C. (2015). Using a Flipped Classroom Approach to Support Problem-Based Learning. Technology, Knowledge and Learning, 20(3), 299-315. https://doi.org/10.1007/s10758-015-9262-8

[20] Tosun, C., \& Taskesenligil, Y. (2013). The effect of problem-based learning on undergraduate students' learning about solutions and their physical properties and scientific processing skills. Chemistry Education Research and Practice, 14(1), 36-50. https://doi.org/10.1039/c2rp20 060k 